\title{
You Know I Love You, Right?
}

James Dolbow, DO

Correspondence

Dr. Dolbow

jddolbow@gmail.com

76-year-old man: "Memory Problems"

An agreeable face warm with energy.

An endearing smile below a wrinkled forehead.

"My wife here wants my memory checked," he shrugs.

"She says I'm forgetting things. I think she's overreacting."

Their fingers intertwine where they fit best.

The pattern on their socks match.

Looks at her with an adoring stare.

Back to me with a hint of fear.

With his other hand, the fingers pale.

Pressing into the fabric at his knee.

79-year-old man: "Follow-up Memory Problems"

A slow glance up and then back down to the floor.

Wife with red eyes holds his left hand.

Tightly between her two.

"It's getting worse," she says.

"I don't think the medicine is working."

He looks at her.

Squeezes her hand.

"I'm so sorry, my love," he cries.

84-year-old man: "Weight Loss, Follow-up Memory Problems"

A distant gaze.

A kind and gentle, slow smile.

Red, sleep-deprived wife's eyes. The pattern of fractured glass.

Voice trembling, she asks, "Is he still in there?"

She begins to cry.

Quiet. His socks bunched about his ankles.

"I love you so much," she says desperately.

He gazes up at her. Eyes distant. Hands together. Gentle smile.

No response.

Adjusting to face him, tearfully she asks, "You know I love you, right?"

\section{Acknowledgment}

The author thanks William Rogers for literary guidance. 


\title{
Neurology
}

\author{
You Know I Love You, Right? \\ James Dolbow \\ Neurology 2021;96;287 Published Online before print January 5, 2021 \\ DOI 10.1212/WNL.0000000000011225
}

This information is current as of January 5,2021

\section{Updated Information \& Services}

\section{Subspecialty Collections}

Permissions \& Licensing

Reprints including high resolution figures, can be found at: http://n.neurology.org/content/96/6/287.full

This article, along with others on similar topics, appears in the following collection(s):

All Cognitive Disorders/Dementia

http://n.neurology.org/cgi/collection/all_cognitive_disorders_dementia Assessment of cognitive disorders/dementia

http://n.neurology.org/cgi/collection/assessment_of_cognitive_disorder s_dementia

Clinical neurology examination

http://n.neurology.org/cgi/collection/clinical_neurology_examination Cognitive aging

http://n.neurology.org/cgi/collection/cognitive_aging

Prognosis

http://n.neurology.org/cgi/collection/prognosis

Information about reproducing this article in parts (figures,tables) or in its entirety can be found online at:

http://www.neurology.org/about/about_the_journal\#permissions

Information about ordering reprints can be found online:

http://n.neurology.org/subscribers/advertise

Neurology ${ }^{\circledR}$ is the official journal of the American Academy of Neurology. Published continuously since 1951, it is now a weekly with 48 issues per year. Copyright @ 2021 American Academy of Neurology. All rights reserved. Print ISSN: 0028-3878. Online ISSN: 1526-632X.

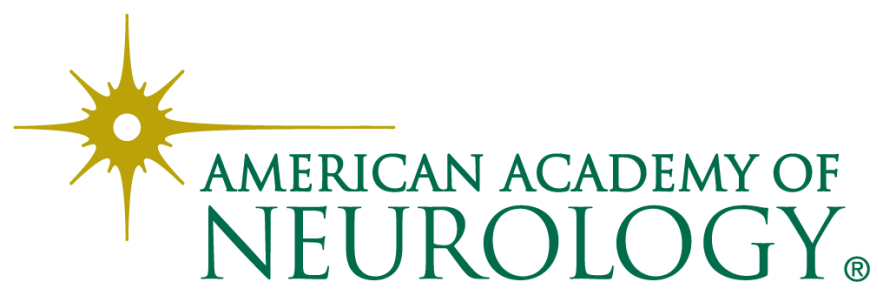

